\title{
Experiences of a Prisoner During the Civil War In and Out of the Hands of the Rebels
}

BY John Stortz

Co. A, 2ND Batt., 16th U. S. Infantry

John Stortz was born in Wurttemberg, Germany in 1842 and emigrated to America with his parents in 1849. At the age of 20 he enlisted in the U. S. Infantry and was with Sherman's Army on its "March to the Sea." He was captured at Atlanta, Georgia July 23, 1864.

The following is copied from an account he kept from that time until he rejoined the the Union Army. After the war, he returned to his home in Winnesheik County and became a farmer. He married Emily Headington in 1871, and with her raised a large family. Stortz died in his eighties, leaving his family in and around Decorah.

All spelling, punctuation and capitalization has been left as he wrote it.

July 23d, 1864, while on vidette post in front of Atlanta, in company with Benjamin Selsby (our post was behind a large wind-fallen tree in thick timber) we heard firing commence to our right about 10 o'clock in the morning, and a little after I saw the man to our right leave his post and go to the rear without firing his gun or saying a word; and while I was watching him, suddenly some dozen rebels appeared in our front not over 20 yards distant. They told us to surrender, "You Yankee sons of ${ }^{\circ}{ }^{\circ}-\circ$ ". Selsby fetched his gun to his shoulder, but before he could fire it he was shot dead by the rebels. I surrendered, for that was all the chance I had for my life. The men that captured me belonged to the 17th Mississippi. I was taken through Atlanta with about twenty others that were captured that morning and marched to East Point, 5 or 6 miles south of Atlanta where they kept us a couple of days with about 2000 other prisoners that were captured on the 22nd, the day McPherson was killed, and a good many Iowa boys among them.

On the morning of the 25th they started us south and marched us as far as Griffen where we arrived on the 27th. 
Here they put us in box cars, and we got a ride toward Andersonville where we arrived about 1 o'clock on the 28th. Here we were counted off into detachments of 270 men or three nineties and marched inside; but, oh, what a sight our eyes met! Thousands of men crowded together in a lot or stockade - no shelter whatever provided by the rebels; some half naked and not even a blanket to shelter them from the hot sun in the day or the dew at night. I was lucky, for the rebels left me my blanket; and as it was the middle of the afternoon when we got inside the stockade, we got nothing to eat, as they only gave the prisoners rations once a day, commencing about $10 \mathrm{~A}$. M. and getting through about 2 P. M.

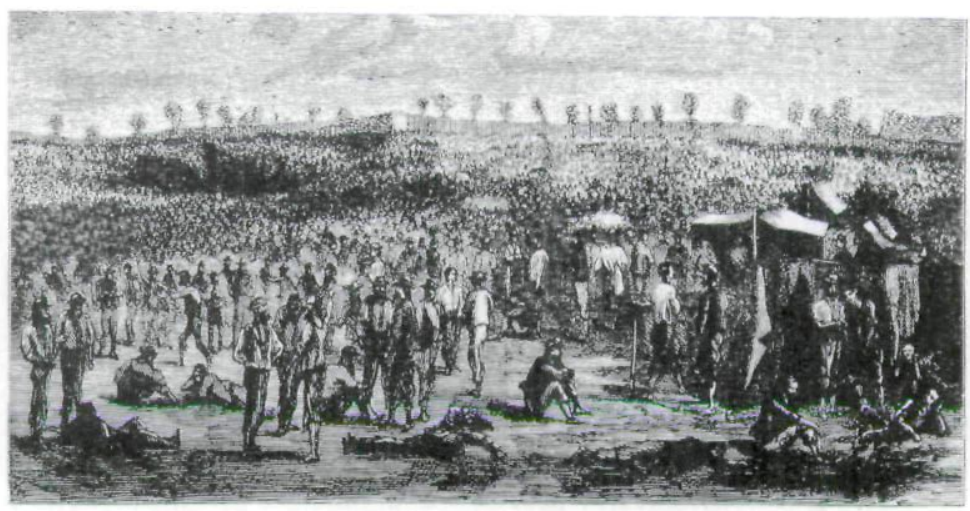

Andersonville Prison

I was the only man captured from my Company and so was among strangers. When night came I rolled myself in my blanket and tried to sleep but could not. I had always thought that prisoners were treated like men and not penned in a lot like hogs; but here I was and knew I must make the best of it. Next day I found Frank Dorsey and Paul - - - of the 16th U. S. Infantry - my Regiment. They invited me to come to their tent which was made by stretching two old blankets over a pole, the pole rested on low stakes drove into the ground; so I cast my lot with theirs while at Andersonville. 
The number of deaths as reported inside the prison was about 100 per day for the month of August. Dysentery and scurvy were the principal ailments. We were not allowed wood enough to cook what little they gave us, although there was plenty of timber in sight. Our men would fight among themselves for a chance to help carry out our dead so as to pick a few sticks of wood up and bring back with them. I helped carry out one man - forgot his name. Pat Sadge helped carry him out to the Dead House, which was a large tent. But who could describe the sight which met our eyes? There were forty or fifty dead men lying there side by side, many with their eyes partly open, their hands crossed and tied, their toes tied together, a slip of paper pinned to their breast with name, company and regiment written on. From here the rebels hauled them by wagon load and buried them in trenches.

About the first of September there was a rumor in camp that we were going to be exchanged; and a few days after, they began taking the prisoners out, commencing with the first detachment, on the morning of September 10th. I slipped out with my bunk mates and was put on board the cars. They gave us two days rations and told us we were going to Charlestown, South Carolina to be exchanged. Went through Macon, Augusta - on to Charlestown. Here they switched off and ran north. Next day some of the boys jumped off the cars and took for the woods. Arrived at Florence about sun-down on the 13th. Stayed on the cars all night with nothing to eat, this being the third day since we left Andersonville with two days' rations. 14th - This morning they marched us about a mile from town into a field and put guards around us, and we got about a pint of corn meal per man. 15th - This day about noon, while waiting to go out with a squad after water, I saw boys getting rails on the other side of the camp. I started across, thinking I would get some too. When I got to the fence I could see some of the boys going into the timber, and away I went as fast as my legs would carry me through the brush and timber, passing a good many of our boys. After a while I was alone, got to a creek and followed it down stream. Could see a man's tracks 


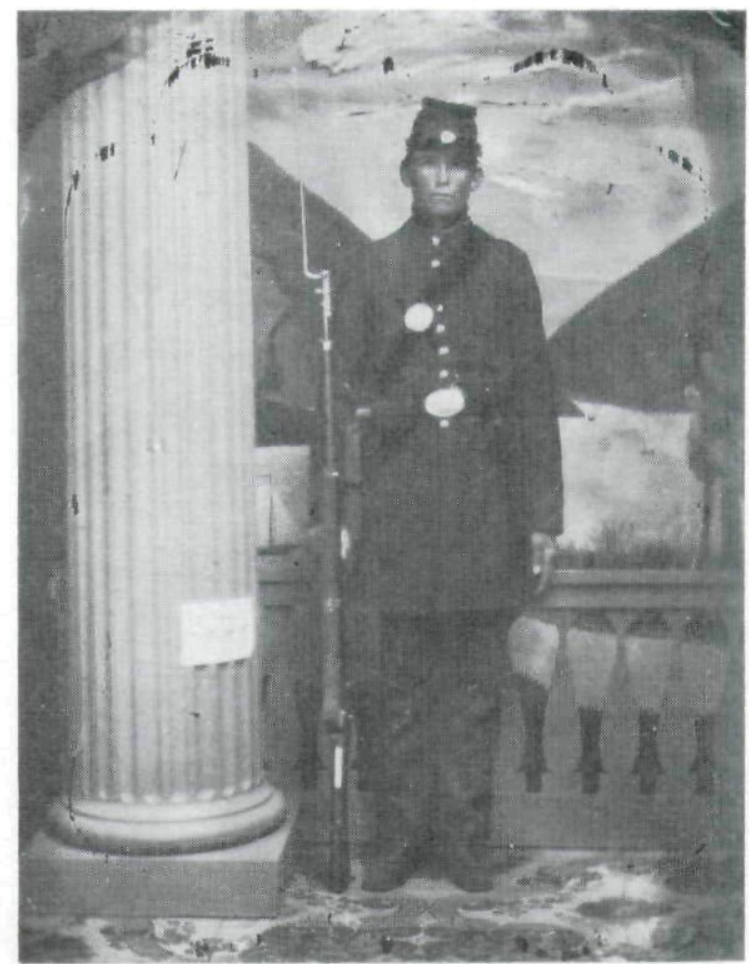

JoHn StoRtz

in the mud going in the same direction, but never got sight of him. At dusk I got to the bank of the T Dee River and stopped all night under a large elm tree. Had two ears of corn which I ate most of during the night. Next morning I made a raft out of some drift wood, stripped my clothes off and pushed off for the other side, swimming and pushing the raft with my clothes on top ahead of me.

I stayed in the timber until toward night when I got onto a road, travelled most of the night. Next day lay in the timber - a lonesome day it was for me. Got some corn out of a field close by which I ate raw, and found some wild grapes which tasted good. At night I commenced tramping again; it was a very dark night. About midnight I met three rebel deserters - got within a few feet of them before I knew they 
were there. They told me they lived in S. C. and were from near Richmond. About 2 A.M. it commenced raining. Stayed under a friendly tree till daylight with nothing to eat. Was wet and hungry. It stopped raining some time in the morning, and I started to follow the road, not caring much where it led to.

About noon I saw two Negroes in the timber. They told me to look out or I would get captured. Followed the road about half a mile farther when a man halted me. He was in the timber, side of the road, and I got past where he was before I saw him, and he took me to his house about a mile distant, he gave me something to eat and some cider to drink. Afterwards. told me he was looking for two Negroes that were hiding in the woods. His name was Calvin Black. Mrs. Black gave me a suit of old clothes to put on while one of the servants washed and dried mine. She also gave me a pair of socks, for which I always felt thankful. Next morning Mr. Black took me to the railroad station in his carriage and on to Wilmington where he turned me over to the rebel authorities, and I was locked up in the military prison. They kept me there three days, and then in company with four other prisoners was put on board the cars and sent to Florence.

Arrived at Florence about $10 \mathrm{P}$. M. We were put into a building on the side of the railroad track with thirty or more other prisoners which had been recaptured. Next morning on looking over the building I saw there was no floor overhead excepting 3 or 4 boards in one corner. Going up a pair of stairs and stepping from one joist to the next, I walked to where the boards were. I lay down, and a few minutes after, another man came over to where I was and lay down. It wasn't long after when the rebels marched the rest of the prisoners off to the camp or stockade, leaving us two lying on the boards. We lay there until some time afternoon when a man came into the building and stayed a few minutes and went out, but it made us feel uneasy; and as it was only about thirty feet into a corn field, we came to the conclusion that we would like to get there, as we hadn't had anything to 
eat, or at least myself, since the morning before we left Wilmington. The roof of the building that we were in projected over on both sides some 8 feet, covering a kind of platform. The rafters were about a foot wide, resting on a plate or timber of the main building, leaving a space two feet long and a foot wide for a man to crawl through, and through we went into the corn field.

Starting north through the timber, walking till dark. After dark we found a road which we followed to the Peedee River which we crossed in a canoe. Next day we stayed in the woods all day, sleeping most of the time. We had some sweet potatoes and corn to eat but nothing to make a fire with, so we ate them raw. After dark we started following a road east; we thought of going to Newborn on the coast, not knowing anything about the distance. Walked all night. A little before daylight in the morning we passed the buildings of a plantation. Just as we passed a man crossed the road behind usdid not speak. We thought maybe he hadn't seen us as he was carrying a lantern. We hadn't gone over a mile when we heard hounds behind us, so we left the road, ran across a field into timber. We hadn't gone far when we came to a stream of water. As my comrade could not swim I left him there, telling him to climb a tree. I have forgotten his name; he belonged to the 40th N.Y. Infantry.

I plunged into the water and swam across, swimming some distance down stream before landing. I followed the river some distance, listening for the hounds. Could hear them upstream and men halooing. After a little everything was quiet, so I stripped off my clothes and wrung them out, walked until I found a place where the sun shown through the timber, as it was thick most of the places, so that I could get a little warmth from it, as I was chilly, the air being cold. Stayed in the timber till the middle of the afternoon, when I started to find my way out of the woods. Walked until nearly night. Saw a Negro driving some cattle; spoke to him, asking where I was, and telling him to get me something to eat if possible, as I hadn't had a bite that day. He told me to wait till after dark and he would bring me something, so I 
stayed. After dark he brought me some corn bread and onions, and told me where I would find the road to Fayetteville, N.C. Thanked him and started. I stayed in the timber daytimes, traveling by night till I reached Fayetteville where I tried to cross the Cape Foar River on the bridge and was captured by a guard that was stationed at the bridge.

The rebels took me up to the Arsenal and locked me up in the company with two negroes. Here I stayed three days, when they put me on board a steamboat which the rebels furnished and sent me down the river to Wilmington in company with the negroes with nothing to eat; but as I had got to looking out for myself I managed to get some sweet potatoes and apples out of a sackful of the boat's freight; and as it got dark before we reached Wilmington, I filled a sponge coffer which I picked up in the Arsenal at Fayetteville. So I filled it with apples and sweet potatoes. When we left the boat I carried my forage with me. I also got hold of an empty gunny sack. They took me up to the guard house, and locked me up for the night, and the next morning they took me to their military prison, locking me up in a cell by myself, keeping me in solitary confinement for three days. After that they let me out among other prisoners-about forty in all, some rebels who were in for deserting.

Among the Federal prisoners was H. S. Daskam, three Iowa infantrymen, John M. Parks, 31st Illinois Infantryman, John Irwin, Michael White and Tom (forgot his other name) of the 103d Pennsylvania Infantry. Nights we were locked up in the prison; daytimes we would go down into the yard to wash and exercise. Our principal living was rice and not much of that.

On the morning of October 19th the Union prisoners-16 in all-were called in line and marched down to the ferry landing. While waiting for the boat an oldish lady came down with some cold victuals and began giving to the boys. When the guard told her we were Yanks, she flew mad, telling us "You'uns come down to fight with we'uns, burn our houses, kill our children" and so on, giving the rest of her provisions to our guards, 14 in number. As we crossed on the ferry boat, I saw a blanket rolled up lying on a shelf 
near the boiler, and watching my chance I captured it.

We were put on the cars and started for Florence, 110 miles west. There were some rebel soldiers on the cars with us going home on furlough. One of them-a jolly fellow-he bought fruits and other eatables from peddlers, white and black at different stations, buying all they had, dividing it among the prisoners, and when the signal was given to start would hand them out their baskets, letting on as though he wanted to pay them, but the train getting under such headway, he failed to do it.

A little before dark I noticed John M. Parks going to the water closet. A little after another man went in. The rebel guards, getting suspicious that something was going on, one of them looked in. The birds had flown, or rather the men had opened the window and jumped out while the train was in motion. The Rebs. then counted their men and found four had gone, two belonging to the 12th N.Y. Cavalry-don't know their names. Arrived at Florence at half past 9 P.M. Our guards turned us over the Officer of the guard with the remark that we were a slippery set of Yanks. He had better keep a close watch of us.

We were marched into a small barn about 30 feet long with a guard at the inside of the door with orders not to let us make any noise. We soon felt the inside of the building over. As it was dark we could not see. We found one board a little short in the floor, so by cutting it off once it would make an opening large enough for a man to crawl through. There was a rebel sailor with us; they were taking him to Mobil for some offense. I had seen him have a dirk knife at Wilmington, so I asked him to let me have it for awhile as I wanted te cut out. I got the knife going to work with a good will, some of the other boys standing guard. Had been to work a short time when the Officer of the Guard with a file of men came in, having a light with them and lots of hand cuffs. As soon as they came in I spread a blanket over the place where I had been cutting, lying down on it. They put hand cuffs on all the boys. At last the officer came up to where I lay, telling me to get up. I kept my place, groaning. "What's the matter," he said. I told him I was sick. "How long have you 
been sick?" H. S. Daskam spoke up, telling the officer that I had been sick over a week; that the doctor at Wilmington had been giving me medicine. "I will not hand cuff a sick man," the officer says and started out with his file of men telling the guard at the door not to let us make any noise. As soon as the officer was out of sight with his light I went to work again, the other boys walking around to make as much noise as they dare to drown the noise I made cutting with the knife.

The other boys spelled me some but as they had hand cuffs on they could not work to good adanvtage. Twice during the night the Rebs. came in with a light to see if all was safe. As soon as they appeared with their light I would spread my blanket over the hole and lay down.

Between 2 and 3 in the morning we got the board cut through. It was pitch pine and as hard to cut as oak. I crept over to where the sailor lay and whispered to him that we had a hole cut large enough to crawl through; to come on if he wanted to go with us. He said he would stay and go to Mobile. The five of us that had worked together crawled out, not daring to wake the other prisoners. There were 7 of them (Federal) within a few feet of us that did not know we were cutting to get out. We did not dare to let them know for fear of being discovered. Here I will say I have heard it remarked that the prisoners, or many of them, were glad to lie in rebel prisons, as they were not in as much danger as they would have been serving in our army at the front. But I know that they worked night and day jumping off from trains while in motion, running the risk of getting killed or crippled. We crawled out under the floor, making good our escape. Four of the boys had hand cuffs on-H. S. Daskam, 3d Iowa, John Erwin, Michael White and Thomas (forgot his surname) of the 103d Pennsylvania.

Taking the railroad north toward Charaw we traveled as fast as we could till near daylight. We met a Negro. The boys showed him how they were handcuffed; he said he could get them off. We hunted until he found a tie rotten enough so that he could pull a spike which he used as a hammer, and the rail of the road answering the place of an anvil, the boys 
holding their wrists on the rail, he, the negro, hammering till he had broke the last one, the boys throwing them into the bushes side of the road where I suppose they still lie. At daylight we went into a corn field to hide, where we met two Negroes and a white. The white man was a deserter from the rebel army. They were all hiding like ourselves. We stayed with them till night, eating corn to still our hunger. At dark we asked the men if there were any sweet potatoes in the neighborhood. They told us that there were lots of them. One of the Negroes volunteered to go and get some for us if one of us would let him have a pair of shoes, as he would not go barefooted in the dark. I pulled off my shoes; he put them on and started. That was the last I saw of my shoes or the treacherous negro. We waited until about 9 oclock when we gave up all hope of his coming back. I got the other Negroe's shoes, the white man agreeing to get my shoes back for him, from the one who fooled me out of mine.

We traveled the balance of the night, following the railroad. We dug some sweet potatoes. Camping in the timber the next day, we built a fire, roasting and eating potatoes, sleeping by turns, one being on guard all the time. After dark we started again, following the railroad till near daylight. We found some sweet potatoes during the night. At daylight we hid in the woods near a small stream, resting and sleeping during the day. In the afternoon some pigs came near where we were picking up persimmons which they seemed to like. John Erwin got his hat full of persimmons. Going to where the pigs were, he commenced feeding them, finally getting hold of one which we killed. We cooked it all before we left camp in two little tin pails. If we did not have a feast, there never was a set of men that did.

After dark we started out again, following the railroad track. Passed through Cheraw about midnight; dug some sweet potatoes. Hiding in the woods and roasting potatoes during the day, at dark we started again, following the plank road toward Wainsboro, where we arrived about midnight, October 24th. We stopped at the outskirts of the town parleying among ourselves as to which way was best to gowhether to the left and miss the town or go straight through 
the town. The majority was for going through the town and that's the way we went till we met two "patriots" who ordered us to halt. Michael White and Tom were a little way behind and took to their heels, making good their escape, while John Erwin, H. S. Daskam and myself were marched up to jail and locked up. Here we fared the best of any place that I was a prisoner in. Mr. Patrick, our jailer, was kind to us, also his daughters, two of whom brought our meals, pushing them through a space under an iron grated door. The next day a couple of ladies living in Wainsboro came to see us, as Yanks were a curiosity. They plied us with all sorts of questions which we answered to the best of our ability.

On the morning of the 27th, the Misses Patrick told us while we were eating breakfast that we were going to be sent back to Florence; would start that morning. So we went to packing up our things; and if Mr. Patrick missed a double wool blanket, I could tell him who got it, for it went out of that jail in my bundle. We were taken to the Provost Marshall's office and turned over to two home guards. One of them, Dr. Huntley, tied us together with a rope or cord. He commenced at Daskam by tying his arms together behind him, myself next, then Erwin, so I had the honor of being in the middle. The guards got into the buggy drawn by one horse and told us to march which we did.

They were armed with a double-barreled shotgun and one Colts revolver. We kept the road, talking in a low tone as to our chances of getting away from our guards. They were taking us to Cheraw, distant 28 miles, which they wanted to reach by 7 o'clock, which was the time for the evening train to leave for Florence. They stopped at plantations to feed their horse and eat their dinner, which they kindly divided with us. After eating they tied us with the rope and once more started toward Florence. My feet were sore, as the negro's old shoes wasn't a good fit. I did not walk as fast as our guards wanted to go. One of them spoke to me telling me to walk faster, and he would let me ride a piece after the road got better. As it was swampy where we were, the road was corduroy; that is, logs cut and placed 
one against the other, which is a very hard road for a footsore person to walk on. I told the guard to let me ride across this corduroy piece of road, as when we got to where the road was better I could go bare-footed. He took me at my word, got out of the buggy, untied John Erwin, then myself, which left Daskam with his arms tied behind, but as the rope wasn't very tightly drawn he could use his hands some. I got into the buggy sitting on the left side of the guard, passing my right hand behind him. I got hold of his gun and commenced pulling it. He noticed it and calling to his comrade, he let got the lines and grabbed the gun, putting his whole heft on the gun. I then with my left hand grabbed him by the seat of his pants, throwing him out of the buggy, he still holding his grip on the gun. As he held the butt of the gun and I the muzzle, it was getting dangerous for me. So I jumped out of the buggy and wrenched the gun from him, but in the scuffle we both let the gun go and clinched, I throwing him, but he rolled me, and we were pulling hair when the other boys came up to my assistance, the other guard making no resistance to them. As they were two to one he had no chance to use his revolver. They begged for us to give them back their arms, but as the boys had handed me the revolver I thought I would keep it. The shotgun we gave them back after drawing the loads out.

We took to the woods, leaving our guards standing on the road. We traveled till dusk through the timber across fields, avoiding houses and roads. At night we camped in the timber near a stream, built a fire and cooked some beans which we had gotten in a field. Next morning we started again, having made up our minds to travel by day and avoid roads and houses; but as some days were cloudy and rainy so we could not see the sun, it was hard getting along.

We were in the woods some four or five days living on beans when one evening we saw a Negro near a plantation. I volunteered to go and ask him for something to eat, which I did, telling him that I was a Yankee soldier trying to get back to our lines and that there were two more with me. He told me he would get us something to eat; and, pointing to a large tree, told me to get my comrades and wait there till 
he returned which I did. He was gone about half an hour, and when he came back we could see that there were other men with him, but whether white or black we did not know till they ordered us to surrender which we did, I putting my revolver into my harversack and covering it with sweet potatoes. They searched us and then marched us up to the house. The Negro had betrayed us to his master; and there was a rebel soldier staying there who had been wounded, also a preacher who was going to preach in that neighborhood the next day, which was Sunday. All three armed themselves with two shotguns and an old pistol and took us in. The planter's name was Austin, "Squire Austin" they called him. He treated us kindly, his women folks got us a good supper and as they had sent out word, quite a number of neighbors came in to guard us during the night.

Sunday morning after breakfast we started for Monroe, the County Seat of Union County, in charge of two men horse back, armed with revolvers. As the county was thickly settled, we were in sight of houses and people nearly the whole distance-not a very good place to get away from them without being seen by many other people. We arrived at Monroe about noon and were put in jail. Imagine our surprise on entering the building to see our former comrades, White and Tom in before us, having been captured. We let on not to know them while any of the rebels were in hearing. During Sunday afternoon and evening a number of the ladies of Monroe came in to see the "Yanks," as they called us.

Next morning after breakfast we were started for Charlotte, the nearest railroad station, in charge of two guards armed with Belgian muskets, bayonets fixed, ten rounds of amunition in their cartridge boxes. We started a little after sunrise, one of the guards walking behind us, about ten paces behind us; the other, a sergeant, walking to one side of us most of the way, keeping out of our reach. The distance they told us, was 26 miles to Charlotte. From there we were to take the train to Salisbury Prison. We tramped along with them the most of the distance without any interest of note, excepting that an old planter that was going the same di- 
rection we were, riding a horse, caught up with us, giving us a lecturing as he thought we were rebel deserters under guard to our regiments. He told us that he had two sons in the army, and that if either of them would come home without permission, he would turn him over to the authorities and never again own him as his son. After he got through, Daskam told him we were prisoners who had escaped from Florence, and he said something about hanging being too good and started on ahead.

We arrived at a creek about 4 in the evening where we stopped to get a drink of water. One of the guards asked Daskam to hand him a drink which he did; but as we had no understanding among ourselves, we missed a good chance of capturing our guards. After we got on the road again Daskam came up to me, scolding me in undertones for not seeing him wink to me when he handed the guard the water. I told him not to mind it as we would get away from the guards yet. John Erwin was very foot-sore, as he had marched about 22 miles and his shoes being worn through, so he lagged behind. I stayed back long enough to whisper to him that if I could get close enough to the sergeant to grab his gun I was going to do it if he would keep the rear guard from shooting me. He told me that he would keep his eyes on me; and as soon as I made a grab for the sergeant's gun he and White would attend to the rear guard. We went about half a mile when we came to where there was a muddy place at the side of the road. The sergeant either had to walk through the mud or walk close to me. I saw my chance. The Sergeant had changed his gun from his shoulder, carrying it in his right hand. I cast one look at Erwin and made a spring for the sergeant's gun which I grabbed by the small of the stock. He pulled and twisted, but as Daskam and Tom came to my assistance it was no use. Three Yanks were too much for one rebel. Erwin and White captured the other guard. We made them give us our jack knives and Daskam's memorandum book I am copying at present. The guards begged us to fire off their guns and let them have them back which we concluded to do. We snapped two caps on one gun but it would not go off. If we could have known in 
what condition their guns were we could have left them by taking to our heels without disarming them.

We took their cartridges from them and started into the timbers as fast as our legs would carry us, traveled some three our four miles when we stopped to rest. Here we concluded that we had better go in two squads-Daskam and I going together; Erwin, White and Tom going together. We divided our matches and salt, shook hands and parted. Have never heard of either one of them since.

Daskam and I travelled till way into the night, falling over logs and brush. At last we made down our bed in a fallen tree top, sleeping the balance of the night. Next morning we saw that we were only about 20 rods from a field of corn which extended to the railroad which runs from Columbia, S.C. to Charlotte. We were afraid to cross by daylight, so we stayed in the woods till dark when it began to rain. Toward morning we tried to make a fire but our matches had got wet and wouldn't burn. After daylight we started, lost our course and came to the railroad again. This was a cold rainy day with nothing to eat but corn and beans raw which we could find in the fields. We came to a long house in a small clearing which we watched for awhile. Seeing no persons about we went in by crawling through a window, searching for something to eat. Found half a loaf of dry bread and some onions which we took. Also we took one quilt and a cotton shirt. Traveled two or three miles; but as we could not tell which direction we were going we built a shelter out of some rails and a rubber poncho which Daskam had. It was a cold berth, this being Thursday night, Nov. 3d. We hadn't had anything warm to eat since Monday morning. At daylight next morning it was still raining; and as Daskam had got a bad cold he was getting discouraged, proposing that we go to some house and give ourselves up, which I refused to do. About 9 in the morning it stopped raining, the wind changed to northwest, blowing a gale, soon drying the brush and timber as well as our clothes. About noon we could see the sun through the clouds. It never was more welcome to us, as we had no compass, consequently had to travel by the sun. Cloudy days we would lose our course in 
the timber and were obliged to stop. The last three days had been cloudy most of the time.

We bundled our blankets, which had got nearly dry, and started. Travelled a couple of hours when we came to a small log house standing by itself. We went up to it for the purpose of trying to get something to eat, which we got. There was an old man and two women in the house. We passed ourselves for Confederate soldiers going home on furlough. This was Friday afternoon and the first warm meal we had since we left Monroe Monday morning. We got to the Catawba River about 4 P.M. The river bank was full from the rains. We followed up the river about a mile when we came to a house. We went up, inquiring where we could cross the river. There was a woman and two children in the house. She told us that by going down stream a mile and a half we would come to a large plantation on opposite side of the river where they kept a boat to cross the river in; and if the boat was on the other side, to halloo and a negro would bring the boat over. We asked her what the chances were for getting something to eat. She told us if we could wait awhile she would bake us some bread, which she did. It was the first bread made from wheat flour we had since we were prisoners. Warm bread, butter and milk went well for supper. We thanked her for her kindness as we had no money to pay.

Starting back down the river as directed by the woman, we soon got where we could see the boat on the other side, but hallooed lots of hallooing till we could make the people hear on the other side. When they did hear, a Negro came over after us with the boat. We told him that we were Reb. soldiers going home on furlough, had stopped to see some friends, were off the main road, out of money, but would pay him if we ever happened to see him when we had money. Asked him what the show was for getting some cold victuals. He told us he thought it was good. We went up to the house. After a little, a girl came out and gave us some cold meat and bread. Thanked her and started; travelled till dark. Then we made a bed by gathering some leaves, sleeping sound all night. 
Next morning the sun came out clear. After eating our breakfast which we had got the evening before after crossing the river, we started, taking a north-west course. In the afternoon we stopped at a house, asking for something to eat, which was given us. We tried to pass ourselves off for rebel soldiers, but it would not work for there was a rebel soldier in the house, wounded, belonging to the 49th N. C. Infantry. He had been to the front and knew our uniform. He talked of arresting us and, stepping to the door, hallooed to his father who was working in the field. We told him the best thing he could do was to keep still; and showing him a revolver, it did not take much coaxing to keep him still. His mother set some cold victuals on the table for us, which were eagerly partaken of by us. Thanking her for her kindness and bidding her soldier good-bye, we started on our journey. We travelled all night, keeping in the timber.

Sunday, the 16th of November, the sun came up clear. After shaking our blankets, we started on our tramp, taking a north-west course through fields and timber, avoiding all large houses stopping only at small houses which we found away from any settlement. Stopped at three different houses asking for something to eat but were denied each time. About 3 o'clock in the afternoon we went up to a house, telling the folks our true condition, confessing that we were Union soldiers who had escaped from prison. They gave us a good dinner and directions as to our best course. We tramped on till dark when we came to an old log house filled with corn fodder where we stayed all night.

Monday was cold and cloudy. Started out early, tramping till afternoon. Stopped at a farm house 3 miles from Shirley where Mr. Roberts lived. Got something to eat and tramped on, leaving Shirley to our right. We came to a river about the middle of the afternoon which was too deep to wade. We traveled down stream for some time when we saw a boat at the opposite side. I volunteered to get the boat as Daskam was not very well. Stripping off my clothes I swam across, untied the boat, paddling it over. It was a cold job and made my teeth chatter before I got my clothes on again. We 
tramped along the balance of the day, camping in the timber all night.

Tuesday morning we stopped at a house for something to eat. Asked an old man who was cutting wood. He told us to go to the house; the women folks would give us something, which we did. Got a good breakfast of sweet potatoes, corn bread, meat and milk. There were 7 biscuits on the table made from wheat flour, which we put into our pockets when the lady's back was turned that was waiting on the table. They asked us to stop and rest ourselves awhile; but as a boy and a young woman had disappeared that were at the house when we first got there, we came to the conclusion it was not a safe place for us to rest. We made for the timber as soon as we were out of sight from the house where we found four children from about 6 to 14 years old. We asked them where their folks were. They told us they were over to Aunt Mary's. Asked them for some bread. They told us they had none baked; there was meal in the barrel, and if we would wait they would bake us some. We found out that their father was a rebel soldier, home on furlough. I asked them to get us some sweet potatoes which they started to do. There was some beef drying by the fire place. I took part of it and a fine tooth comb. Did not wait for the children's return with the potatoes, but started on our way. We travelled about an hour, when we sat down on a $\log$ to try the comb. It worked well, for we caught from 6 to a dozen at a haul. Combed our heads thoroughly and felt much relief, for both of us were covered with vermin, having had no comb and no change of clothes for months. We would stop some days when not too cold and skirmish up and down the seams of our clothes, catching the largest ones and dropping them in the leaves to starve. Camped all night in the timber.

Wednesday morning after daylight we started. During the afternoon we came to the foot of the South Mountains. Stopped at a house where we got something to eat, also a few matches which we were very thankful for. We stayed all night in an old deserted house. We made a fire and roasted some potatoes, staying all night.

Thursday morning we started. The country was very 
hilly; hard traveling through the woods. We stopped at a small house in the afternoon. Saw an old man working outside. We asked him for something to eat. He told us he was very poor; was not able to do much work any more; that two of his boys were in the army at Petersburg, one was at home minus his left hand. He said he knew we were Yanks by our clothes. He further told us that the $3 \mathrm{~d}$ house down the valley a rebel soldier lived that was comfortably fixed; that he was home on furlough; that our chance was good for something to eat there, but to look out, for he might send some of his folks off for help to arrest us. We found the house and man was digging potatoes. We asked him what the chances were for something to eat. He told us to go to the house; he thought the women folks would get us something. Daskam went to the house, I staying on the fence watching him dig potatoes till supper was ready. We all went in to eat but a boy about 14 years of age. After supper they asked us to stay all night. I asked him where his boy had gone. He told me to one of the neighbors on an errand. Asked him whether he hadn't sent him for help to arrest us, which he finally admitted, but wanted to know why we thought so. We started off without much ceremony, following the road for some distance. Then we took to the left, following a bridle path over the hills toward Bridletown gold diggings. We camped all night in the woods.

Friday morning, the 11th, left early, the weather being cold and clear. Tramped over hills and through valleys till we came to a small stream which we followed down stream. We stopped at a house where we passed ourselves for rebs. and got something to eat. Toward evening we came to the Catawba River again. Inquired of a man as to where we could cross. He gave us directions, telling us where we could find a canoe to cross in. We found the canoe, paddling it across and tying the canoe where we landed. We followed the river for three or four miles when, as we were passing a house, a man came running out, asking if we were running away from the army. We told him no, we were going home on furlough. "Look here", he says, "if your furloughs are not all right, you better not try to go through Turkey Cove Gap, 
for there is a camp of home guards there, and they will arrest you and send you to your regiment." He gave us directions to a man's house by the name of Alec Dobson, but when we came to the path which he told us would take us to Dobson's place, we were afraid it might be a trap to catch us, so we kept to the right of the road and crossed a creek and climbed the Linnville Mt. We went up till night overtook us, then we scratched some leaves together in a laurel thicket where we stayed till after sun-up.

On Saturday, the 12th, we started out, climbing from one spur to the next. We began to think we would never get to the top. We finally reached the top at 11 o'clock A. M., then commenced the descent, which was hard work. It often was nearly perpendicular. We would let ourselves down by holding to bushes and vines. About 3 P. M. we got down in to the valley. Went up to a house and asked for something to eat, which we got. We were both hungry as wolves. We thanked the woman for her kindness, starting up the valley on the Burnsville road. Followed the road till dusk; and while I was inspecting an old house to find some potatos, a man came up to where Daskam was, asking him if he wasn't a Yankee soldier. Daskam told him he was. "Well," he says, "I thought so." Then he told Daskam that he had been conscripted in the rebel army, but had ran away from Petersburg and got home again. He told us that about a mile from where we then were, on our road the first house we would come to a man by the name of Francis Biddick lived; that he was a Union man; that we could get supper there. We found the house and man as represented; got our supper and directions as for the best road for us to go, and names of other Union men where we would be allright. This man, Biddick had a son that was conscripted, but the rebels could not get him for he was hiding in the woods. After supper we started out, tramping for a couple of hours, the night being cold and windy. Seeing a very thick laurel thicket we went in, staying till Sunday morning.

After sun-up we got up shook the dirt and leaves from our blankets and started on to a man's house by the name of John Henry Deal where we found a welcome and got a good 
breakfast. He gave us directions to a man by the name of John Sparks where we arrived Sunday evening. We got our supper. The old man told us to go up into the timber on the side hill to stay all night, as the rebels were watching his place pretty close; and if it was not safe for us to come down to the house in the morning, they would hang a sheet on the line, but if there was no sheet out to come down and get our breakfast which we did. We helped the old man pick corn on Monday. Saw his son-in-law that evening, who belonged to some Tenn. Union regiment, and was in there for the purpose of getting recruits which he intended to take through to Knoxville Tenn. We thought of staying and going through with him and his squad. After staying nearly two weeks in the neighborhood, where there were more Union people than rebels, we made up our minds not to wait any longer.

So after dark on November 25th, a Mr. Joseph Tolley went with us a piece on horseback and set us across the Tom River, giving us directions as to our course. We tramped all night; it was cold and cloudy. The ground was froze some but not enough to keep our feet dry very much, and then we would step on some ice, and breaking through, it would get our worn-out shoes full of water and ice. It was a hard night's tramping on us.

At daylight we arrived at Mr. Garland's having successfully passed the militia camp on Kane Creek. Mr. Garland directed us to a Mr. Isaac Whitson, a Union soldier in Colonial Miller's regiment, where we got breakfast. He told us it was not safe at the present time to try to reach Knoxville, as the Union forces had been driven from Bull's Gap, and that we had better stay in that neighborhood till it was safer to get through to our lines.

We stayed in this neighborhood for several days. Here we traded our Colts navy revolver for two pair of shoes to a Mr. Buchanan. After getting whole shoes on our feet once more, we felt so much better that we concluded to start for Knoxville after breakfast on the morning of the 29th, which we got at Mr. Garland's. We started crossing the Iron Mt. and the state line between Ten. and N.C. We got supper at a Mr. Miller's in Lime Stone cave. Camped all night in the woods. 
Wednesday, 30th, we went down the valley toward Flags Lands. Met Dr. Bell of the 13th Tenn. Regiment, who gave us directions as to our course to Rock Creek, where we found a house in which lived a good Union man by the name of Stuard. He gave us supper, and we slept all night in an old building on his place. He told us that Colonel Parker's rebel cavalry was a few miles below in the Grassy Cove Valley.

On the morning of Thursday, Dec. 1, we left our friend and went over near the river where we met a Federal soldier belonging to Colonel Miller's regiment. He told us that the rebel general, Vagn, with his army was between Greenville and Knoxville. Therefore, it was not safe for us to try and get through to our lines at present. So we returned, going to a Mr. Guner's where we got something to eat. Then went up into the woods to spend the night.

After finding a good laurel thicket, we gathered some leaves and made down our bed for the night. We lay down, but had not been there long when we heard some men talking and coming toward where we lay. We kept still, not knowing whether they were friends or foes. They came within a few rods of where we were lying, when we heard them gathering laves to make their bed for the night. Next morning Daskam crept over near where they were to see who they looked like, and found that they were escaped prisoners, or rather four of them were. The other three were southerners trying to get through to the Union lines. The leader of the squad was Captain Danby of the 31st Ill. Inf. They had escaped from Florence S.C. Capt Danby had a pocket compass and a small map of the Southern States, which were of great value to him, dodging through the country.

Daskam and I joined them, making 10 of us in all. We all went together to a Union man's house by the name of Ischam Morris. His folks treated us well, giving us all breakfast, dinner and some corn bread to take with us. That afternoon we parted with Capt. Danby for the reason that ten were too many in one squad to go together, for the reason that many 
poor people could give 2 or 3 a meal but could not do so with ten.

That night we slept in a laurel thicket again, as laurel made a very good shelter, the leaves staying on them in the winter months. Next morning, Saturday, Dec. 3, we went down the valley a ways and found six men who were staying in the Mt. to keep out of the rebel army. We joined them and went with them up to their camp in the Mt. Two of them were brothers by the name of Rancy.After dark they told us to go with them down on the river bottoms to get some provisions. They told us that there was a wealthy rebel living down there who had a plenty of everything. We went with them; there were 8 of us in all. We crossed the river in a canoe. Going up to the plantation, they went to the hog pen and killed two hogs, cut their heads off and took out their inwards, cutting them in halves. They took some wheat and some apple butter. After they had all that we could carry we started back for the Mt.

Sunday we cooked meat and slept a good part of the day in camp. The Rancy boys took some of the meat down to their families who lived in a ravine not far from the river. We carried some of the wheat down where the women folks got it and took it to mill and got it ground for us.

On the 5th the rebel soldiers came into the cove, or as we would call it, valley, again, but as the women folks in the valley hung out washing in certain places as a signal, their husbands and brothers always knew that soldiers were in the valley and, of course, stayed up in the Mt. On Tuesday, the 6 th, we moved our camp further up the Mt. to a more secluded place. On Wednesday, the 7th, rebel soldiers were searching the Mt. for us, but as the Rancy boys knew every foot of the ground, we kept out of their way by climbing to the top of the Mt. and staying till night when we returned to our camp and stayed all night.

Dec. 8th. This morning was cold and frosty. After eating our breakfast we sat around the fire trying to keep warm. About 10 o'clock AM as Daskam had gone about 6 rods up the hillside he heard someone talking down in the main ravine, and by careful watching he got sight of 
some rebel soldiers going up the main ravine. While he was watching them they saw the smoke from our fire and turned back down the ravine. Daskam told us what he saw, and we weren't long getting out of there. We hurried through a laurel thicket and made for the top of the Mt. where the Rancy boys left us, telling us that there were too many of us together, and we had better take care of ourselves and they would do the same. That's the last we saw of them. Toward night we returned to our former camp and found the cooking utensils broken up and our provisions gone. We slept all night in a laurel thicket.

Next morning, the 9th, we found the way back to Mr. Morris's where we got something to eat, having fasted since the morning before. After getting something to eat, we went up a ravine about half a mile by direction of Mr. Morris, who gave us an old ax and some matches so we could make a fire. The weather was cold and windy, snowing a little during the day and night. About three inches of snow fell, but as we made a shelter in a fallen tree top by pulling brush over some of the limbs and having a fire, we got along as well as we could under the circumstances we were placed in. Saturday I went down to Mr. Morris's to get us something to eat, going back over the hills by direction of our friend, so in case any of the rebel soldiers were following my tracks, we could see them before they should get close to us. Sunday Daskam went down to get us something to eat and find out whether the rebel soldiers were in that neighborhood any more. As the soldiers had not been seen since the 8 th, we thought we would start next morning.

Mr. Morris' folks baked us a pone of bread, and Monday morning we bade them farewell and started for Knoxville, the weather being cold. We crossed the Chucky River in a canoe, a woman coming across after us while two men stayed on the other side afraid to come over for they thought we were rebels and they were in hiding to keep out of the rebel army. We thanked the woman, having nothing to pay her with for her trouble. We inquired of her the way to Uncle James Tinker's some eight miles distant, having been previously informed that he was a good Union man, where we 
arrived in the afternoon. Mr. Tinker received us kindly and told us the day was so near gone we better stay all night before crossing the Big Butt Mt. We got our supper and stayed all night in the woods. Here we fell in with another Federal prisoner who had escaped from the Rebs. at Bristol, Tenn. by the name of Brooks. He lived about 30 miles from Knoxville up the Holston River. We remained together all night.

Next morning we went down to the house where we got our breakfast. This was Tuesday, the 13th of December. After breakfast, Uncle James Tinker gave us directions as to our course over the Big Butt Mt. We thanked him for his kindness to us and started on our way, following a bridle path over the Mt. We were all day getting across. The ground was covered with about two inches of snow. While going over this Mt. I saw a bear's tracks in the snow. We arrived at a house on Horse Shoe Creek where a man by the name of Henry Beuglar lived, where we got something to eat and a boy of his piloted us to a camp where some Union men were staying, where we stayed all night. Those Union men gave us our breakfast and directions as to our course, and we started on our way. Although it was raining some we traveled about 12 miles when we stopped at a Union Man's house where we got supper and stayed all night in the loft of one of his stables.

Thursday, the 15th, started before daylight down the valley to Mr. Stephens' where we got our breakfast. After that Mr. Stephens got on a horse and rode some distance ahead of us, piloting us some 6 miles to where his daughter lived. Here we got our dinner. They sent a boy to show us where to cross the Chucky River and gave us directions to Mr. Cooter's where we arrived in the evening. Here we stayed all night, sleeping in his barn. The folks treated us kindly; gave us plenty to eat.

Early next morning before daylight, which was the 16th, Mr. Cooter got us on our way, going with us about 3 miles, giving us directions as to our course before he left us. We traveled some five or six miles when we disagreed to our course, I wanting to go north-east till we would come to the 
railroad and follow the track to Knoxville and our east Tenn. friend and Daskam was for keeping in the woods and following by roads; but as we heard that morning that Stoneman's Cavalry, Union, was near Saltville and the rebs. were retreating, I told Daskam that I thought we were running no great risk in taking the rail road back to Knoxville and started, feeling confident that Daskam would follow me. I had gone about half way across the field when I saw some rebel calvary riding along a road some forty rods from where I was. I lay down in a depression in the field and watched them till they were out of sight. Daskam started to follow me, as I thought, after he found I was not going his way; but when he got to the edge of the field he saw the rebel cavalary and came to the conclusion that they had captured me. I saw Daskam about a year after at Decorah, Iowa, when he told me this. He got married shortly after and moved to Mich. where he died with consumption brought on by exposure in lying out in the woods with scant clothing and not much to eat and a great deal of the time, sleeping like a wild beast in a thicket for shelter, which is more than a common man can stand without injury to his health, especially in the months of November and December when the ground was covered a part of the time with snow.

I started out alone after the rebel cavalry was out of sight, feeling lonesome enough that night. I stayed all night with a Union man by the name of Isaac Rible some three miles west of Greenville, Tenn., sleeping in one of his stables. $\mathrm{He}$ gave me directions to the $R$. road which I followed all day without dinner. It rained a little most of the day. In the evening I stopped at a house, asking for somthing to eat, which I got, and stayed all night, sleeping on the floor by the fire place, as my clothing was wet. Mr. told me to stay in the house or I would take cold.

After breakfast I started, following the R. Road track, and tramped along all day alone. I missed the company of my former comrade; It was a lonesome tramp - a cloudy, rainy day. I drudged along till toward night. I stopped at three different places before I got anything to eat and a place to 
stop all night, but have forgotten the man's name. He used me well, giving me my supper and breakfast. I slept all night in his house on the floor. He and his wife offered me a bed, but I told them that it had been over two and a half years since I slept in a bed. I would not rest well, and besides my clothing was full of gray-backs. So they consented to my sleeping on the floor, where I rested comfortable all night.

After breakfast I resumed my tramping along the railroad. In the afternoon I stopped at 3 or 4 places, asking for something to eat but was refused every time. At dusk I arrived at the R. Road bridge crossing the Holston River where I was halted by the Federal soldier guarding the bridge. He called the Corporal of the Guard who sent a man with me to Headquarters where I reported to Major Newal of the 10th Mich. Cavalry, who sent me to his regiment with an order for the boys to provide for me during the night which they did to the best of their ability. They got me some supper, consisting of hot coffee, fried bacon and army bread, or hard tack, as we generally called it. After supper they furnished me with a suit of clothing, one giving me a pair of pants, another a pair of drawers, still another a shirt and so on till I was clothed from head to foot with a change of clothing. My old rags they rolled up in a bundle and throwed out in the street, and there was many a gray-back got chilled in them that night, for it was cold and freezing.

Next morning I got an order for transportation to Knoxville, where I arrived about noon and reported to General at Headquarters. Here I received an order for a suit of clothes, blanket, knapsack, haversack and canteen and was sent to a hospoital which was in a large brick building, which I was told had been built for an orphan asylum by the state of Tenn. Here I was treated well. I was sore and lame with Rheumatism and received medical treatment.

December 24th. I stayed in the hospital most of this day. 1 heard by one of the men that the 16th U. S. Infantry was on Lookout Mt. near Chattanooga. As soon as I heard this I went down to Headquarters and asked for transportation to Chattanooga. I received an order and went back to the hospital, staying all night. 
December 25th. This morning I boarded the train for Chattanooga where I arrived in the evening, staying all night at the Soldiers' Home.

December 26th. After breakfast, I went to Headquarters and reported. Here I got a pass and started for Lookout Mt. where I arrived about 10 A.M. and reported to Capt. Sol. S. Robinson of Co. A., 2nd Battalion, 16th U.S. Inf., of whose Company I was a member.

There never was a man gladder in getting home to his famiiy than I was in getting back to my Company.

December 27th. I reported at sick call and received treatment for Rheumatism, which bothered me the rest of the winter, although I done duty some of the time.

\section{Pretty Girls At The Empire}

\section{Bewildering Display of Feminine Charm in the Cherry Blossoms Company}

A bewildering bundle of pretty girls and handsome costumes mark the leading characteristics of the Cherry Blossoms, which appear this week at the Empire in the double burlesque of "The Girl I Met in Sherry's" and "Look Out Below." Strange to say, every girl is handsome save one, and the management has found a place for her in the back row in the bouncing blues-dispeller, which the company dispenses during the two hours of relaxation and recreation.

Dainty pantomime pictures of swimming and bathing girls, interior views of artists' studios give a class to the performance in keeping with as gorgeous a lot of costumes as shown this season on the stage of this popular house.

Lydia Carlisle, "the girl with the diamond garter," made a clever hit in dancing, Eddie Mack, the old-time burlesque favorite, and Minnie Granville in clever Italian impersonations, received a hearty applause for work of a class rarely seen in burlesque. 
Copyright of Annals of Iowa is the property of State of Iowa, by \& through the State Historical Society of Iowa and its content may not be copied or emailed to multiple sites or posted to a listserv without the copyright holder's express written permission. However, users may print, download, or email articles for individual use. 